\title{
Mikołaj Kopernik doctor decretorum
}

Prawo Kanoniczne : kwartalnik prawno-historyczny 16/3-4, 4-6

1973

Artykuł został zdigitalizowany i opracowany do udostępnienia w internecie przez Muzeum Historii Polski w ramach prac podejmowanych na rzecz zapewnienia otwartego, powszechnego i trwałego dostępu do polskiego dorobku naukowego i kulturalnego. Artykuł jest umieszczony w kolekcji cyfrowej bazhum.muzhp.pl, gromadzącej zawartość polskich czasopism humanistycznych i społecznych.

Tekst jest udostępniony do wykorzystania w ramach dozwolonego użytku. 
Kanoniści polscy, łączac się $w$ Roku Kopernikowskim $z$ caIym światem naukowym $w$ hołdzie składanym geniuszowi Mikolaja Kopernika, szczyca sie, że jako „doctor decretorum” tak chlubnie zapisal się $w$ historii nauki. 


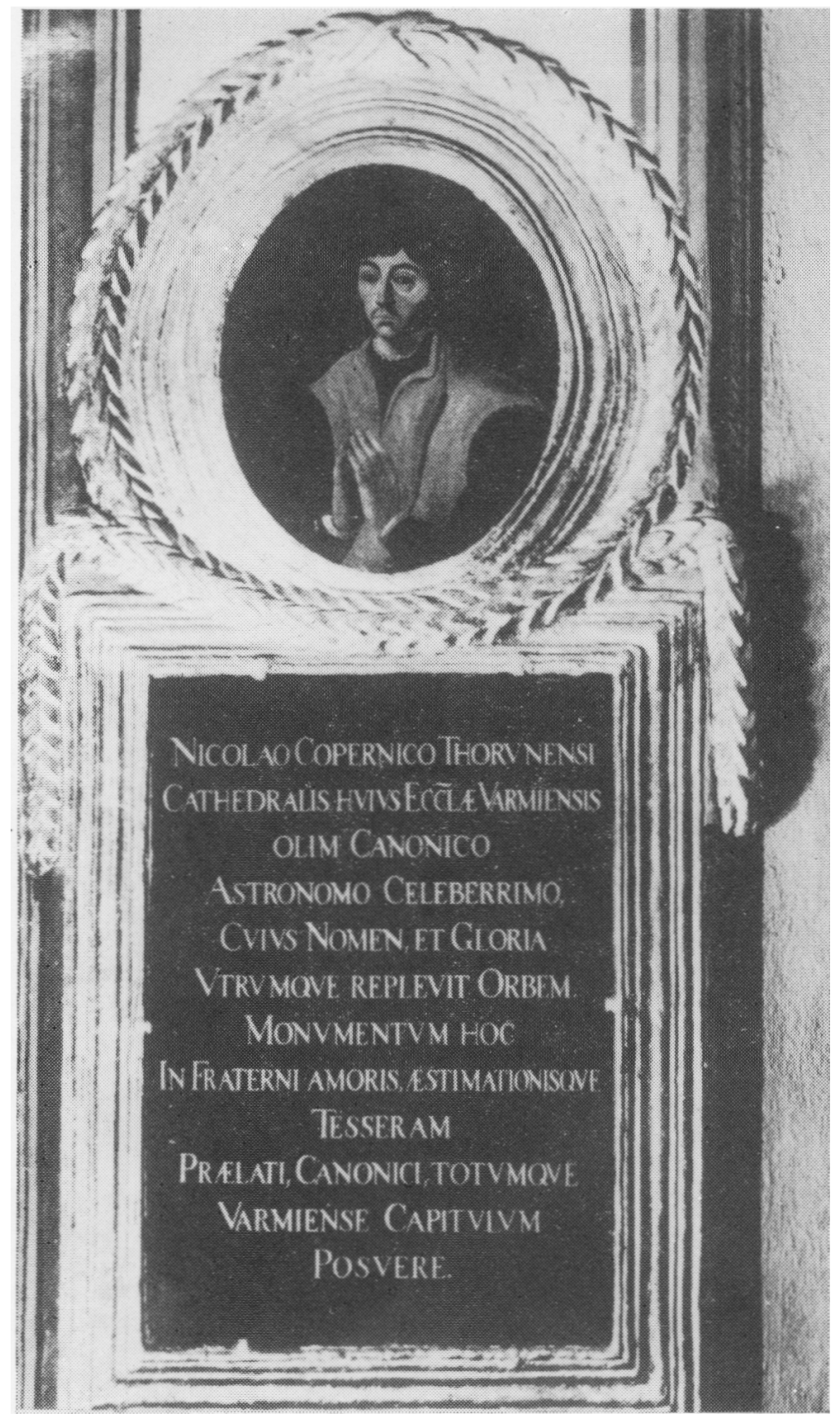

Epitafium M. Kopernika w katedrze fromborskiej 


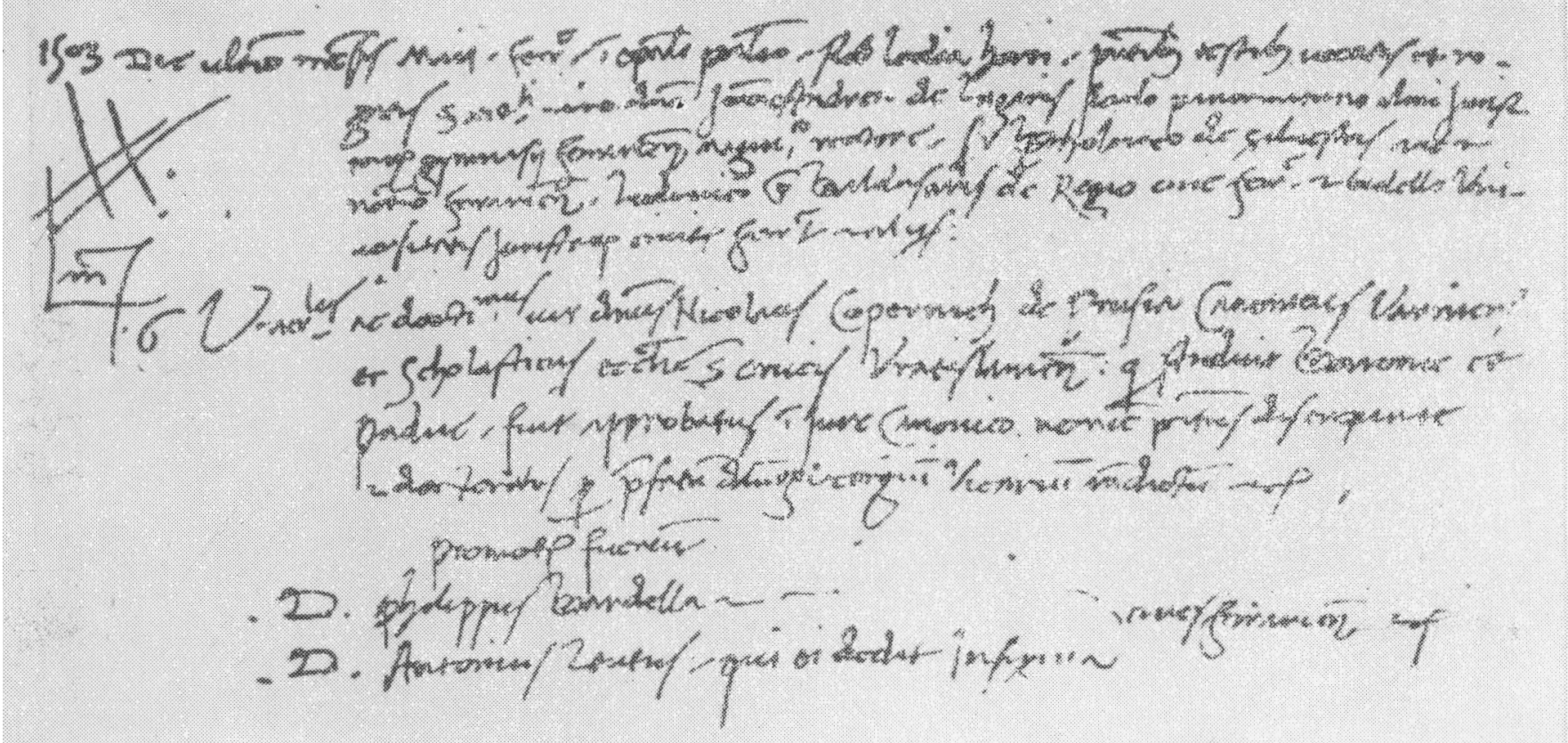

Kopia protokołu promocji doktorskiej M. Kopernika 